\title{
1. General introduction
}

The notions (if not the terms) of 'dumping' and 'anti-dumping' have been part of the bilateral trade treaties and domestic regulations since the progressive market opening of the early 1800 s. However, the first time that these terms were used in a trade context similar to the current one was in 1904, by Canada's Liberal government which, although backed by a free trade (in theory) party was facing pressures from domestic manufacturers and farmers to increase import duties in order to protect Canadian industry from foreign dumping (Viner 1923). However, during the 50 years following the end of the First World War, anti-dumping as a trade instrument remained largely a sleeping beauty, mostly because the bulk of protection was ensured by tariffs, quantitative restrictions, subsidies, or a mix of all these instruments. From the early 1900s up to the late 1970s, anti-dumping was thus a relatively minor trade provision allowing Customs to take action in a limited number of cases, despite its introduction in the 1947 GATT text.

Things started to change dramatically during the 1970s. From the 1960s to the early 1970s, the US and the EC were mostly using voluntary export restraints (VERs) or minimum prices (trigger price mechanism) for coping with the increasing relative inefficiency of their labour-intensive activities (textile and clothing, shoes and so on) and of the steel sector. However, all these instruments showed major flaws in their capacity to protect. They tend to attract a lot of public attention. They have to be renewed and tightened frequently because imports from the rest of the world continued to increase, often under the form of upgraded varieties. They offer limited scope for discriminatory measures between efficient and inefficient foreign producers, between foreign competitors and foreign allies, and they have to be paid systematically by giving up rents to the foreign producers.

In all these respects, once it started to be used, the anti-dumping instrument has rapidly shown its ability to offer a 'better' solution (from the importcompeting firms' perspective) than VERs and grey measures. As a result, starting from the late 1970s, the total number of anti-dumping investigations and measures has steadily increased. ${ }^{1}$ Until the early 1990 s, the anti-dumping

1 Many scholars have studied the proliferation of AD duties and the reasons behind this phenomenon. Prusa (2001 and 2005) offers a very comprehensive look at Petros C. Mavroidis, Patrick A. Messerlin, and Jasper M. Wauters 
Table 1.1 The main anti-dumping users: number of cases, 1995-June 2006

\begin{tabular}{lcrr}
\hline & $\begin{array}{c}\text { Number of } \\
\text { initiations } \\
1995-2006\end{array}$ & \multicolumn{2}{c}{$\begin{array}{c}\text { Measures in force } \\
\text { (July 2006) } \\
\text { taken by }\end{array}$} \\
\cline { 3 - 4 } & & Number & Share (\%) \\
\hline India & 448 & 323 & 17.2 \\
United States & 366 & 236 & 12.6 \\
European Community [c] & 345 & 224 & 11.9 \\
Argentina & 209 & 149 & 7.9 \\
South Africa & 199 & 116 & 6.2 \\
Australia & 188 & 69 & 3.7 \\
Canada & 138 & 84 & 4.5 \\
China, P.R. & 126 & 83 & 4.4 \\
Brazil & 125 & 66 & 3.5 \\
Turkey & 106 & 97 & 5.2 \\
Mexico & 89 & 82 & 4.4 \\
Korea & 82 & 47 & 2.5 \\
All Top 12 countries & 2421 & 1576 & 84.1 \\
Developed countries [d] & 1119 & 660 & 35.2 \\
Developing countries & 1302 & 916 & 48.9 \\
All other countries & 517 & 299 & 15.9 \\
Other developed countries [e] & 186 & 136 & 7.3 \\
Other developing countries & 331 & 163 & 8.7 \\
All countries & 2938 & 1875 & 100.0 \\
\hline
\end{tabular}

Notes: [a] Ratios of measures in force in 2006 to initiations over 1995-2006.

[b] Ratio of measures taken by the country to measures taken against the country.

[c] Source for measures in force against the EC: European Commission, November 2006.

[d] US, EC, Australia, Canada, Korea.

[e] Hong Kong, Israel, Japan, Lichtenstein, New Zealand, Norway, Russia, Saudi Arabia, Taiwan.

Source: WTO Secretariat, 2007. Author's calculations.

this issue. Finger and Nogues (2006) have studied anti-dumping practice in seven Latin American countries (Argentina, Brazil, Chile, Colombia, Costa Rica, Mexico and Peru). They confirm that the use of anti-dumping has increased substantially over the years. In their view, however, such use is a necessity, since otherwise the countries Petros C. Mavroidis, Patrick A. Messerlin, and Jasper M. Wauters - 9781848440142 


\begin{tabular}{|c|c|c|c|c|c|}
\hline \multirow[t]{2}{*}{$\begin{array}{l}\text { 'Productivity' } \\
\text { [a] } \\
1995-2006\end{array}$} & \multicolumn{2}{|c|}{$\begin{array}{c}\text { Measures in force } \\
\text { (July 2006) } \\
\text { taken against }\end{array}$} & \multirow[t]{2}{*}{$\begin{array}{l}\text { Case } \\
\text { balance } \\
{[\mathrm{b}]}\end{array}$} & \multicolumn{2}{|c|}{$\begin{array}{l}\text { Measures in force } \\
\text { in } 2006 \text { taken (per } \\
\text { USD billion of trade) }\end{array}$} \\
\hline & Number & Share $(\%)$ & & by & against \\
\hline 72.1 & 69 & 3.7 & 4.68 & 0.507 & 0.143 \\
\hline 64.5 & 100 & 5.3 & 2.36 & 0.023 & 0.021 \\
\hline 64.9 & 103 & 5.5 & 2.17 & 0.027 & 0.013 \\
\hline 71.3 & 13 & 0.7 & 11.46 & 0.970 & 0.057 \\
\hline 58.3 & 34 & 1.8 & 3.41 & 0.367 & 0.121 \\
\hline 36.7 & 8 & 0.4 & 8.63 & 0.103 & 0.014 \\
\hline 60.9 & 12 & 0.6 & 7.00 & 0.044 & 0.006 \\
\hline 65.9 & 353 & 18.8 & 0.24 & 0.026 & 0.099 \\
\hline 52.8 & 69 & 3.7 & 0.96 & 0.147 & 0.115 \\
\hline 91.5 & 22 & 1.2 & 4.41 & 0.173 & 0.061 \\
\hline 92.1 & 25 & 1.3 & 3.28 & 0.058 & 0.019 \\
\hline 57.3 & 132 & 7.0 & 0.36 & 0.033 & 0.086 \\
\hline 65.1 & 940 & 50.1 & 1.68 & - & - \\
\hline 59.0 & 355 & 18.9 & 1.86 & - & - \\
\hline 70.4 & 585 & 31.2 & 1.57 & - & - \\
\hline 57.8 & 935 & 49.9 & 0.32 & - & - \\
\hline 73.1 & 541 & 28.9 & 0.25 & - & - \\
\hline 49.2 & 394 & 21.0 & 0.41 & - & - \\
\hline 63.8 & 1875 & 100.0 & 1.00 & - & - \\
\hline
\end{tabular}

examined would have no way to make adjustments they needed to, in light of the liberalization commitments they undertook since the Uruguay Round. In other words, the countries examined view recourse to anti-dumping more as a safeguard, rather than as a response to an unfair practice. 
cases were mostly initiated by developed countries. Since then, they have been initiated by developed and developing countries alike. Table 1.1 presents the world anti-dumping activity during the last decade, with details for the top twelve anti-dumping users. The 'productivity' ratios (the measures enforced with respect to the initiations) range from 36 to 92 per cent. These figures are high, all the more because the ratios underestimate the productivity of the anti-dumping proceedings since their denominators are defined over a period of time (11 years) much longer than the legal period of anti-dumping enforcement (generally between three to five years). They strongly suggest a huge bias in the WTO and domestic regulations. ${ }^{2}$

Table 1.1 deserves another important observation. The apparent similar number of cases initiated and enforced by industrial and developing countries is misleading from an economic perspective. In fact, anti-dumping is likely to have a more negative impact on developing economies than on industrial countries, for two reasons. Firstly, there is a marked difference between the number of measures imposed by developing countries and industrial countries, once adjusted for trade size. The average number of measures in force per billion US dollars of goods imported by an anti-dumping user is a better indicator of the potential impact done by anti-dumping to the domestic economy than the absolute number of measures. This indicator is much higher for developing countries than for industrial countries, ranging from 0.05 for Mexico to 1.0 for Argentina and from 0.02 for the European Union to 0.04 for Canada (with an exception, Australia, at 0.1). These differences would be even greater if the number of anti-dumping measures were adjusted for the number of tariff lines concerned since developing countries tend to cover many more tariff items with anti-dumping cases than do industrial countries. Secondly, available information suggests that anti-dumping duties enforced by developing countries are, on average, higher than those imposed by industrial countries and economic analysis shows that the welfare costs generated by tariffs increase more rapidly than tariffs do.

A final preliminary observation to keep in mind is that, during the last two decades, anti-dumping rules have shown an extraordinary capacity to evolve. Over the past 25 years, the EC and the US have amended their anti-dumping statutes half a dozen times. More importantly, this drift has always been in one direction, making it easier to prove the existence of dumping and injury and of a causal link between dumping and injury, as illustrated by the two following

2 There have been huge efforts to provide databases on anti-dumping cases initiated and enforced by WTO Members. Such databases are not simple matters since the anti-dumping procedures are so complicated (especially if one takes into account the reviews). The most complete source is provided by Bown, and it is posted on the following website: http://people.brandeis.edu/ cbown/global_ad. 
examples. Imports can now be deemed unfair even if foreign firms charge higher prices to their export market than they do at home. The definition of 'less than fair value' was broadened to capture not only price discrimination, but also sales below cost. This chapter presents anti-dumping as related to price discrimination because this was the initial view - and it may be still the most important one although, in the US, cost-based cases account for more than onehalf of the lodged anti-dumping cases (Clarida 1996). But the lesson of the past 25 years is that 'losing a case is not a sign that the foreign competition is traded fairly, rather it is simply a sign that the anti-dumping law needs changing' (Bloningen and Prusa 2003). In this context, the WTO dispute settlement mechanism role is essential because the Dispute Settlement Understanding (DSU) appears the only source (so far) of possible counterweights to the general drift towards systematically weakening anti-dumping disciplines.

\section{A DUMPING: AN UNFAIR (?) TRADE PRACTICE}

\section{Dumping is Price Discrimination}

The WTO Agreement on Antidumping (AD Agreement) is probably the single most heavily criticized agreement, predominantly by economists, but increasingly in the legal scholarship as well. Criticism is directed at various aspects of the agreement, but focuses on the very idea to 'punish' price differentiation. For the AD Agreement imposes a legal constraint on WTO Members wishing to impose $\mathrm{AD}$ duties but, in principle, accepts the idea that dumping can be 'punished'. And dumping is nothing more than price differentiation, whereby the export price is lower than the price in the home market of the exporter (the normal value). The latter price (the normal value) is very often constructed and it is not an actual price: the domestic investigating authority has the legal right, assuming certain conditions have been met, to neglect an actual market price, and construct a fictitious price which will serve as one of the two benchmarks to decide whether dumping exists.

Dumping is only one of the conditions that must be satisfied for AD duties to be lawfully imposed: it must further cause injury to the domestic industry producing the like product. In a nutshell, if a domestic producer has suffered injury as a result of price differentiation practised by its competitors, it can lobby its government and request protection through the imposition of $\mathrm{AD}$ duties. ${ }^{3}$

3 As will often be repeated in this chapter, the AD Agreement endorses an injury to competitors standard; see on this issue Hoekman and Mavroidis (1996) and Finger (1993). Hoekman and Mavroidis (1996) include their empirical research in the petros C. Mavroidis, Patrick A. Messerlin, and Jasper M. Wauters 


\section{Price Discrimination in Antitrust Statutes}

The thrust of criticism has to do with the treatment of price differentiation. In antitrust practice, which is not necessarily by definition the best reflection of cutting-edge economics, ${ }^{4}$ but which has been substantially more open to economic analysis, price differentiation is not treated in the way it is treated in the AD Agreement. Of course, there is nothing like a world antitrust statute and hence, ipso facto, no harmonized practice either. A look into two quite well-known systems, the EC and the US, is appropriate.

The European Court of Justice (ECJ) had the opportunity to pronounce on this issue in its Akzo and Tetrapak case-law. ${ }^{5}$ In the EC system, price differentiation will be treated as an abuse of (single or collective) dominance. So, for price differentiation to enter the picture of antitrust enforcement, a prior finding on dominance is required. We quote from the last decision (para. 41) which is the most recent one and can be considered the authentic expression of the test for predatory pricing established by the ECJ:

In AKZO this Court did indeed sanction the existence of two different methods of analysis for determining whether an undertaking has practised predatory pricing. First, prices below average variable costs must always be considered abusive. In such a case, there is no conceivable economic purpose other than the elimination of a competitor, since each item produced and sold entails a loss for the undertaking. Secondly, prices below average total costs but above average variable costs are only to be considered abusive if an intention to eliminate can be shown.

With respect to some of the sales at hand, the ECJ found that the prices charged were between average variable and average total costs. According to its own test hence, it would have to show intent to eliminate the competition. The ECJ in para. 44 ruled as follows on this point:

EC jurisdiction: the European Community has a public interest clause, whereby AD duties will not be imposed unless they meet the statutory requirements of the WTO Agreement, and also meet a statutory requirement mandated by EC law, namely, that the duties eventually imposed serve the public interest. They found that practice of meaningful application of this public interest clause had been extremely scarce. Moreover, although intuitively one would expect that under this clause the (EC) domestic investigating authority would evaluate the implications of imposition of $\mathrm{AD}$ duties on EC consumer welfare, this has almost never been the case. Not much has changed since they published their study.

$4 \quad$ See Hovenkamp (2005) pp. 12ff.

5 See Akzo Chemie BVv Commission, Case C-62/86 [1991], ECR I-3359 (July 3, 1991); Tetrapak International SA v Commission Case T-83/91, [1995], ECR II-762 (CFI) and Case C-333/94P, [1996], ECR I-5951). 
... it would not be appropriate, in the circumstances of the present case, to require in addition proof that Tetra Pak had a realistic chance of recouping its losses. It must be possible to penalize predatory pricing whenever there is a risk that competitors will be eliminated. ... The aim pursued, which is to maintain undistorted competition, rules out waiting until such a strategy leads to the actual elimination of competitors.

The US Supreme Court also had the opportunity to pronounce on this issue. In the US statute, monopolization plays the same role as abuse of dominance in the EC regime, and it is under its aegis that the Supreme Court discussed this issue. The leading case is Brooke Group: ${ }^{6}$

A plaintiff must prove (1) that the prices complained of are below an appropriate measure of its rival's costs and (2) that the competitor had a reasonable prospect of recouping its investment in below cost prices. ... The plaintiff must demonstrate that there is a likelihood that the scheme alleged would cause a rise in prices above the competitive level sufficient to compensate for the amounts expended on the predation, included the time value of the money invested in it. Evidence of below cost pricing is not alone sufficient to permit an inference of probable recoupment and injury to competition. The determination requires an estimate of the alleged predation's cost and a close analysis of both the scheme alleged and the relevant market's structure and conditions. Although not easy to establish, these prerequisites are essential components of real market injury. ... Predatory pricing schemes, in general, are implausible ... and even more improbable when they require coordinated action among several firms ... They are least likely to occur where ... the cooperation among firms is tacit, since effective tacit coordination is difficult to achieve; since there is a high likelihood that any attempt by one oligopolist to discipline a rival by cutting prices will produce an outbreak of competition; and since a predator's present losses fall on it alone, while the latter supracompetitive profits must be shared with every other oligopolist in proportion to its market share, including the intended victim.

Although the evidentiary standard in US law is higher and makes the possibility of successfully challenging predatory schemes quite unlikely, both regimes punish only a sub-set of price discrimination: predatory pricing. Assuming that such a scheme has been successfully implemented, the predator will be in a position to recoup the original investment, having driven the competitors out of the market and having ensured that there is no risk, at least for some time, that they will jump back into the market when it will have raised its prices. In other words, what antitrust statutes punish is behaviour which causes injury to competition, as opposed to injury to competitors. Rational economic behaviour by governments would suggest that, before imposition of duties, the welfare implications of dumping on the whole of the 
society, and not simply a sub-set of it, that is the injured producers, should have been examined. This is not the case, though. Thus the AD Agreement is a classic device to protect domestic producers. ${ }^{7}$

\section{Price Discrimination in Economic Theory: Three Stories}

People believe that a firm should charge a price for its product in its home market lower than the price it charges in its foreign market - mostly because they see exporting a product as requiring additional services, such as transportation, marketing adapted to the importing country's consumers, taxes (tariffs) and the rest. Hence, most people consider as abnormal or 'unfair' the cases when the home price of the exporting firm is higher than the price it charges in the importing market. For historical reasons (see above) such pricing is called 'dumping'. By extension, dumping also describes the situation where the costs of the exporting firm in its home market are higher than the price it charges in the importing market. As a result, most people believe that imposing measures counteracting such dumping practices (anti-dumping measures) make sense.

But does anti-dumping make sense from an economic point of view? It is useful to divide the question in two. Does dumping make economic sense; that is, is dumping a quite acceptable pricing behaviour? If not, is the anti-dumping instrument, as designed in the AD Agreement, the appropriate instrument to be used? Economic analysis shows that the most frequent answer to the first question is negative, hence that it is merely another way of protecting importcompeting firms. And it shows that, in the few cases where anti-dumping could make some sense, anti-dumping measures are generally not the appropriate instrument to address the issues at stake.

Anti-dumping supporters invoke three reasons which, in their view, present dumping as an unacceptable pricing behaviour, or, at least, as a behaviour to be limited by anti-dumping measures. First, dumping is a predatory pricing strategy with a strong anti-competitive, monopolizing goal. Second, dumping

7 Sometimes the argument is voiced that AD should be viewed as some form of safeguard: absent some breathing space for economies that have been opened up too abruptly to foreign competition, governments might be unwilling to make commitments (hence, because of the existence of the AD Agreement, meaningful commitments have been entered) and, more importantly, an important lobby might be losing interest in pushing for trade liberalization. The basic problem with this argument is that it conveniently omits to reveal that another WTO Agreement (the Safeguards Agreement) is designed to play exactly this role (and of course, per construction, such is not the function at all of the AD Agreement). So, at best, proponents of this argument would have to explain why the Safeguards Agreement has not fulfilled its original promise for their argument to hold. 
is a discriminatory pricing practice which generates distortions among markets. Lastly, dumping reflects asymmetrical conditions in the exporting and importing markets which give an unfair strategic advantage to the foreign exporter(s) over the import-competing firms.

\section{(a) Predation}

Complaining firms in anti-dumping cases often argue that the foreign exporters are pricing at a price below their home price, or at a price lower than their cost of production (but generally without specifying whether they are talking about total, fixed or variable costs). And they suggest that such a pricing behaviour is driven by the will of foreign firms to eliminate domestic competitors in their own market in order to increase prices when they will be in a monopoly position in the import-competing market. This line of argument dates from the nineteenth century, more precisely from the nascent US antitrust law.

Does this argument make sense from an economic point of view? It hardly does because it takes as granted conditions that are far from being met in the real world.

\section{(i) Predation: unlikely}

Let us assume the simplest possible world in which all the firms operating in a market have the same supply curve, with the same market price $p$ clearing total supply and demand. In this hyper-simple (but very telling) case, all the firms produce, and sell the same quantity on the market.

Let us now assume that one firm, Predator, adopts a predatory pricing strategy in order to eliminate all its competitors, and to become later the monopoly in the market. For achieving this goal, Predator decides to increase massively its supply and to sell a much larger quantity of products than the initial quantity. In other words, Predator decides to 'dump' additional units of the product, hence the term 'dumping'. The immediate consequence of such a policy is to depress the initial market price which falls to an extent which depends on the supply price slope (that is, elasticity).

This new, lower, price has two consequences. The first, and most important, though generally ignored by the anti-dumping supporters, is that Predator is losing money. It sells at a much depressed price many more units. As producing more units imposes sooner or later higher costs (the most general form of a supply curve is to be upward sloping) Predator earns fewer dollars or euros per unit sold, while facing higher costs of production. The more units Predator sells, the more depressed the price is, the more Predator loses money.

The second consequence of the new market price is that Predator's competitors (let us call them Preys) need to adjust to the new (lower) market 
price resulting from Predator's dumping. They can do so by reducing their output since, by the same token, they reduce their costs of production. How successful can they be when following this adjustment process to Predators' predatory policy depends on several conditions, in particular the magnitude of the price contraction, their cost constraints, the duration of the price war, and so on. In a nutshell, the longer and the more severe this adjustment has to be, the higher the risk is that Preys have to leave the market.

To sum up this first phase of predation, Predator is losing money while Preys can survive without losses via adjustment. And the fact that Preys may leave the market reflects the fact that Predator may have to depress severely and for a long time the market price, meaning that it has to suffer high losses for a long time. Predation is not easy. It is a war.

Let us assume that Predator succeeds in eliminating all its competitors. The second phase of predation can begin. Predator can start to increase the market price now that it enjoys a monopoly. But, contrary to appearances, this second phase is for Predator as difficult and risky as the first one. This is because competitors old and new alike could re-enter or enter the market as soon as Predators' increased price is high enough to cover their production costs. In sum, Predator's success depends heavily on whether the entry costs of competitors are low or not.

Predator's pricing is thus a strategy in two phases: eliminating competitors which generates costs for Predator, and 'recouping' these costs during the second phase which almost necessarily creates incentives for old competitors to come back or new competitors to enter a market that they ignored before the price war. Predator should follow predatory pricing only if the second phase brings higher profits than the losses generated by the first phase.

The temporal aspect per se makes the price war much less 'easy' than antidumping supporters suggest. Let us assume that each of the two phases is spread over several years. Then, losses may easily dominate the actualized value of the predatory strategy (actualized value refers to the value of this war the day before entering the war). This is because losses are concentrated in the first years, hence they are modestly discounted (losses in two or three years from now have almost the same value today as the losses of the first year). In contrast, the benefits expected in the second phase are concentrated in years far from the initial date (in four or five years from now), hence they are more severely discounted (benefits in five years from now have not the same value as today's benefits).

Many complications can be introduced into this illustrative tale. Complications mean risks, hence tending to work against the likelihood of predatory behaviour, contrary to what is often believed at a first glance. For instance, let us assume that Predator is a large firm, and Preys are small firms. Predator's 'large pocket' seems to be a strong card in predatory pricing. This ${ }_{81848440142}$ 
argument is far from being as convincing as it looks at first glance because size on the supply side of the market is only half of the story - the other half of the market is its demand side. Assuming that Preys are small compared to Predator, they can try to convince the demand side of the market (the consumers) to help them to survive the first phase of Predator's dumping. They have a good argument: it is that, if Predator wins, consumers will pay a monopoly price. In other words, the consumers of the product in question can 'invest' in a competitive market structure (as long as the costs of support during the first phase do not exceed the benefits of a more competitive market during the second phase).

Interestingly, the size argument does not pass the reality check test. Most anti-dumping cases are lodged by large domestic firms against small foreign firms, suggesting that predation would be a pricing strategy followed by small firms against large firms, a case that does not make a lot of sense. A well-known anti-dumping case illustrates this point. In the late 1960s and early 1970s, the US TV producers launched several AD actions against Japanese TV producers. Their argument was that Japanese firms practised predatory behaviour in the US market. One of these anti-dumping cases went to the US Supreme Court (the so-called Matsushita case). The debates in the Court established that, if they were following a predatory strategy, the dozen Japanese firms would have needed more than 40 years to recoup their initial losses in the US market, a result illustrating the unlikelihood of dumping as predatory pricing. Indeed, available evidence suggests that only a very small percentage of the anti-dumping cases (less than 5 per cent) deal with cases which may have a predatory dimension (Bourgeois and Messerlin 1998; Shin 1998).

(ii) Merger as an alternative to predation

This unlikelihood is supported by an additional argument. If the goal of predation is monopolization of a market, is there a better - less expansive - way for Predator to achieve this goal? The answer is positive, and it is merger. A much less risky and costly way for Predator to eliminate Preys is to buy them, at a price which would reflect their stock value in the expected monopolistic (not in a competitive) market.

This alternative is limited by the constraints imposed by the existing competition policy. But these constraints are the same whether Predator follows a predatory policy or a merger strategy. And they are the same whether Predator is a foreign firm and Preys are domestic firms. In other words, there is no justification for anti-dumping measures.

\section{(b) Discriminatory pricing}

Supporters of the anti-dumping instrument argue that it is 'unfair' that an 9781848440142 
exporting firm charges a price in its exporting market lower than its home market price. As said above, their view mirrors the fact that exporting a product requires additional services, compared to selling at home, such as transportation, marketing adapted to the importing country's consumers, taxes (tariffs) and so on. However, this fact is not as robust as it seems at first glance. It is likely to be cheaper for a producer based in Toronto to sell his products in the US East Coast than the Canadian West Coast. More generally and importantly, economic distances are far from mirroring geographic distances. A world map based on transportation costs (not on geographic distances) is very different from a geographic map. In our modern economies, transportation can be low enough to make attractive the production (or assembly) of goods in far away countries.

\section{(i) Discriminatory pricing: frequent ...}

Leaving aside this crucial gap between economic and geographic realities, the above anti-dumping justification relies on a crucial implicit assumption: the competitive structure of the home and export markets are similar, that is, the exporting firm faces the same kind and level of competitive pressures at home and in export markets.

This assumption is far from being granted. Indeed, it seems much more reasonable to assume that a producer is better known in its home market (and that he knows it better) than in its export market. In other words, such a producer may have some 'market power' in its domestic market meaning that the firm in question can influence the price to be paid by the purchasers of its product (that is, it can get a higher price) by restricting the quantity it supplies. By contrast, because the firm in question has no market power in the foreign market, it cannot expect to influence the price paid by the foreign purchasers of its product.

In what follows, 'market power' is a term that channels no a priori views, whether positive or negative. Such a view depends on the source of the market power. A producer can derive its market power from his ability to produce better conceived or designed goods. Such a market power is perfectly respectable, and it plays an important role - indeed, it is part of the competitive process. By contrast, market power may flow from the exporter's capacity to eliminate competitors in its home markets by some illegal means. Or it may flow from the existence of (private or public) import barriers protecting its home market from foreign competition. Such sources of market power are seen as negative by the economic analysis because they impose unnecessary costs on the consumers. The fact that market power has such a different impact, depending on its source, plays a key role in deciding what should eventually be done, and who should act as shown below. 
If the home and foreign markets have different competitive structures, it is easy to show that the home price charged by the producer is necessarily higher than the price it charges in the foreign market; in other words, that dumping is a perfectly justified pricing strategy (if the existing market power flows from a respectable source). For simplicity's sake, let us assume in what follows that the export market price is a price driven by perfect competition. In other words, there are many sellers in this market for the constant price clearing the market. All of them cover their costs, but make no extra profits, meaning that the price in the import-competing market is the lowest possible price of the product in the world.

If the firm charges a price in its home market equal to this foreign price, it does not make use of its market power, hence it sells too many units of its product in its home market. Because the home price of its product is too low, compared to the price it could charge by using its market power, it gives up the possibility of making extra profits at home.

Using its market power at home requires that the firm restrict the quantities it sells at home. How much 'less' is less? For simplicity's sake, let us assume that selling the same unit in the two markets requires the same costs. This assumption means that costs are not part of the answer to the question raised, and thus that the answer depends entirely on the demand side of the markets (the supply side will play a role in the following section). Before selling each unit in a market, the producer should compare how much he will earn by selling it in the home market, and in the export market. The firm will sell its first unit at home since the home consumers are willing to pay for its product a price higher than the foreign consumers (this is the meaning of market power). However, for every additional unit sold at home, the price (marginal revenue) that the producer could get will decline. As a result, sooner or later, the firm would get the same marginal revenue at home and in its export market. This situation signals that it is time for the producer to shift the next units of the product to the export market where he gets the foreign price which is constant and higher than the successive marginal revenues available at home.

In sum, discriminatory pricing generates two prices for the producer, with the home price higher than the export price. Such a situation is sustainable only if there is no way for a trader (or any other operator) to buy units of the product in the export market, and to re-import them in the home market at a lower price than the price charged by the producer. In such a case (called 'arbitrage') the producer is not in a position to make use of its market power at home.

The absence of arbitrage may flow from intrinsic factors out of reach of the exporting firm, such as logistic infrastructures, distribution and so on. However, one might wonder why goods can be shipped from home to the foreign countries and not vice-versa without the help of more visible hands. Limits to arbitrage can thus be trade barriers imposed by the home country of the exporting firm. Other (more subtle) limits can be devices generated by the 
exporting firm itself for protecting its home market, such as different technologies in the two markets, as best illustrated by imposing different cryption procedures in the DVDs markets. Firms can introduce such designs segmenting markets for more economically sound reasons. For instance, the home country consumers could be much more sensitive to the latest technologies than the foreign country consumers, allowing the firm to sell the no longer fashionable products in the foreign country without serious risks of seeing them shifted back into the home country and sold at a lower price than the ones revealing the firm's market power.

The absence of arbitrage has an important consequence for a key concept in anti-dumping procedure. If generated by economically sound reasons, it strongly suggests that the product sold in the foreign market by the home firm is not 'similar' (a 'like-product' in the WTO legal jargon) to the product sold by the firm in question at home (as in the above example of two technologically different varieties of such a product). In this respect, it is interesting to mention the provision included in the Treaty of Rome (1956) for dealing with intraEuropean dumping. Article 91:2 specifies that all the products exported from one country to another one 'shall, on reimportation, be admitted in the territory of the first-mentioned State free of all customs duties, quantitative measures or measures having equivalent effect'. This provision (abrogated in the 1997 Amsterdam version of the Treaty) was an attempt to test, via the markets' reaction, whether the product in question was a like product, or not (if it did go back to the country of origin, it could be assumed not to be a similar product). ... but not a reason to intervene for the importing country

Let us assume the absence of arbitrage, so that the exporter's home price can remain higher than his export price for some time. This situation provides no justification to intervene since both prices reflect perfectly the demand and supply conditions in both markets. In particular, the fact that the government of the import-competing country would take anti-dumping measures would hurt the consumers' welfare of the import-competing country. In fact, large economies (such as the US or the EU) offer plenty of cases where producers charge in their home (EU or US Member state) market a price higher than the one they charge in their foreign (the other EU or US Member states) markets without any intervention from the 'home' or 'foreign' Member state, or from the 'federal' government. 8

8 The question of providing some 'adjustment' breathing (that is, some time for reacting to rapidly increasing competitive pressures from foreign firms) to the domestic firms of this country is examined in the safeguards section. 
Turning to the exporter's home country, there are two alternative conclusions, depending on the source of the exporter's market power. If this market power relies on economically sound reasons (better product conception, design and so on) there is no reason for the exporter's home country to intervene. The higher price that home consumers are ready to pay is their recognition of these economically sound reasons, while the home product is, in some sense, 'unique'. In sharp contrast, if the exporter's market power is generated by his anti-competitive behaviour at home, there is a good reason for the exporter's (not importer's) home country to intervene by using its competition regulations. Similarly, if the home producer enjoys market power because its home country impedes arbitrage by imposing high tariffs or non-tariff barriers, the exporter's government should change its policy and remove these barriers.

But what if the home country does not want to take the appropriate action (be it a competition investigation or a reduction of import barriers in the home exporter's market)? Anti-dumping supporters argue that the adoption of antidumping measures by the importing country would induce the foreign government to act. This argument is much weaker than it looks at first glance, simply because the importing country's market is small by the world standard (and that is even true for the US or the EU markets). In such a case, an anti-dumping measure would have no impact on the foreign producer (who will concentrate his sales in the other export markets) while it deteriorates the consumers' welfare in the import-competing country.

\section{(c) Strategic dumping}

Discriminatory pricing focuses on pricing differences due to different home and foreign demands (with the home demand being less elastic than the foreign demand). The last type of dumping - strategic dumping - relies on cost conditions. It emerges when an exporting firm benefits from a closed home market where it can charge the full (fixed and variable) costs of production to the home consumers, allowing the sale of the product in the export market at a price including only the variable cost (the import competing is assumed not to be protected). The fact that the exporter's home market is a 'sanctuary' puts the import-competing firms in a difficult situation since they cannot use a pricing strategy mirroring the exporter's approach, but have to charge their full costs to their own consumers. Similar to strategic dumping is dumping associated with sporadic sales, when firms from large countries shift their last discount sales to smaller economies.

There is a condition for strategic dumping to be successful. Import-competing firms should be 'disadvantaged' enough, in terms of the relative size of accessible markets and scale economies, with respect to the exporter operating from the sanctuary market. In particular, strategic dumping is clearly implausible when the exporters' sanctuary market is small relative to the importing market. 
As for the other anti-dumping justifications, there is a need for a reality check which suggests that strategic dumping is not a significant case at the current stage of anti-dumping use. The size argument means that the existence of strategic dumping would only justify anti-dumping measures taken by small countries against exporters operating from large economies. In sharp contrast to this conclusion, evidence shows that a vast majority of the anti-dumping measures taken in the world have been adopted by large economies against small countries. As shown by Table 1.1 above, the top twelve anti-dumping users launch and enforce more than 80 per cent of all the cases and measures notified to the WTO, whereas they represent only 65 per cent of the world imports, and 73 per cent of the 2004 world GDP (at purchasing power parity). These top twelve users are the targets of only half of the measures in force, with a wide range of 'case balances' among the top twelve anti-dumping users. In sum, anti-dumping is currently an instrument enforced by a few large countries against the smaller economies of the rest of the world - a situation not at all fitting strategic dumping.

This reality check requires two caveats. First, the size of the economies as a whole is only a proxy of the size of the markets, and what count in antidumping matters are the markets of the product in question, not the size of the whole economies. It might be the case that a relatively small economy hosts a relatively large market for a given product, while the relatively large economy hosts a relatively small market for the same product. However, the EU and US anti-dumping cases do not see this first caveat as a common one. Second, the above reality check assumes that developing countries use the anti-dumping instrument in the same way as the large industrial countries. It assumes that developing countries do not use alternative instruments to anti-dumping measures, such as straight minima prices or quantitative restrictions. Evidence suggests that they do, so that more refined data are needed. However, it remains that the current use of anti-dumping does not address the strategic dumping issue.

\section{Anti-dumping Enforcement: Lessons from an Economic Perspective}

What precedes amply suggests that the main justifications of anti-dumping in its present form - are weak from an economic perspective. It suggests that anti-dumping, as it is, is a modern form of protection. From this perspective, it is useful to summarize a few economic lessons drawn from past anti-dumping enforcement. The following assessments are mostly derived from the examination of the Australian, Canadian, EC and US cases. But there is no reason to believe that the many cases initiated by the developing countries would lead to different conclusions. These lessons are organized under four headings: the determinants of anti-dumping complaints, the determinants of coving $_{8184840142}$ 
anti-dumping investigations, the direct costs of anti-dumping measures, and the magnified costs of anti-dumping protection generated by the anti-competitive nature of a vast majority of the anti-dumping cases.

\section{(a) Determinants of anti-dumping complaints}

As should be expected with an instrument of protection, the primary determinants of anti-dumping complaints are import penetration, domestic industry employment and capital stock or intensity of the sector (for more details, see Bloningen and Prusa 2003). In the US, where the procedure for the injury test is harder to predict than for the (almost certain) proof of the existence of dumping, import penetration and domestic employment are particularly crucial since they are the most important variables used by the US authorities in charge of injury determination.

That said, two additional questions related to filing a complaint are interesting. Firstly, to what extent does domestic producers' export activity affect the decision to lodge an anti-dumping complaint? The question is of particular interest in a world with an increasing number of anti-dumping users, that is, where a complainant in one country could easily become a defendant in another large economy: sometimes you're the windscreen, sometimes you're the bug, as the song goes. Economic analysis suggests that larger export exposure should dampen the incentives to lodge complaints. Indeed, Zanardi (2004) shows that, to avoid being the bug, WTO Members strategically avoid hitting with anti-dumping duties their trading partners, who are likely to hit them back, and that anti-dumping activity by a WTO Member is likely to provoke anti-dumping activity against it. (However, the expected relation is not always significant, as shown for US filings with respect to Australia, Canada, EC and New Zealand (Bloningen 2000). In addition to the above explanation based on countries' behaviour, another reason relies on firms' behaviour and the capacity of anti-dumping to be used as a anti-competitive device for segmenting world markets (see below, section (d)).

Secondly, do macroeconomic variables (exchange rate variations, real GDP decline) play an important role in lodging anti-dumping complaints? The answer to the exchange rate impact should take into account two opposite forces. When firms are slow in adjusting prices for taking into account exchange rate variations, the chances of finding dumping and/or the magnitude of dumping margin increase. But, by the same token, the chances of finding injury decrease. For instance, a euro depreciation may rapidly decrease the price of the foreign firms' exports to the European markets (the export price) in terms of the foreign firms' currency (the home market price). Hence, it makes easier the finding of dumping, but it also decreases import penetration, an essential component of the injury test. In a country where the injury test is the crucial one, it is thus the impact of a currency appreciation that emerges 
as the dominant factor leading to increased anti-dumping activity (Knetter and Prusa 2000). The impact of real GDP decline on lodging anti-dumping cases has been clearly observed in the US, but the evidence is more mixed in the EU.

\section{(b) Determinants of anti-dumping investigations}

\section{(i) Determining dumping}

During the late 1980s and the early 1990s, there was an increasing recognition of the extent to which dumping determination has been biased. In fact, the focus on injury determination has largely flowed from the realization that dumping determination was an 'exercise in futility' (Palmeter 1991), as best illustrated by the fact that, over the 1990s, the US Department of Commerce issued only three negative less-than-fair value determinations (out of almost 400 determinations) (Bloningen and Prusa 2003).

Not only has dumping been routinely found, but dumping margins have been increasingly high (on average 60 per cent during the 1990s in the US, for instance). Only severe biaises in the procedure can explain such an outcome. A first illustration of these biases is the use of the 'facts available' method in case of no information from foreign firms. In fact, 'facts available' simply mean the facts provided by the domestic complainants. Such a method multiplies by two to three that average dumping margin in the US (Baldwin and Moore 1991; Lindsey 1999) and doubles in the EC (Messerlin 2004). Another severe bias in dumping determination has come from the use of the so-called 'zeroing' method. Under this method, investigators have routinely based their estimates of dumping margins on the average of the positive dumping margins (when prices on the export market are lower than prices on the exporters' home market) while ignoring (by giving a zero value, hence the term 'zeroing') the comparisons with negative margins (when prices on the export market are higher than prices on the exporters' home market). Such a biased procedure leads almost inevitably to dumping margins. (For instance, that would be the case if there was only one negative margin, all the other dumping margins being positive.) And it can also easily lead to high dumping margins.

Although the question of how to define like products is critical at the injury as well as the dumping stage, it deserves to be examined at this point, if only because it comes very early in anti-dumping procedures. The usual approach of the investigators is to rely on the tariff nomenclature, that is, to define the like products by a list of tariff lines, generally defined at the six or eight level of the Harmonized Tariff System (HS). In some jurisdictions of developing countries, all tariff lines at the four-digit HS level are sometimes considered as including 'like products' Of course this approach does not make any sense 
from an economic point of view because it covers a much too wide universe of products, hence it underlines the role of anti-dumping as blatant protectionism.

The like product problem raises the following question: to what extent can a reduced price of a given foreign product have an impact on the quantity produced and on the price of the domestic product? (The fact that this lower price may be unfair or not is totally irrelevant at this stage.) As this question is also crucial in antitrust enforcement, it is useful to look at the antitrust practice. Antitrust authorities examine tests and experiments aiming at revealing prices and quantities interactions, that is, direct and cross-price elasticities. All the products with substantial price interactions are deemed to constitute the 'relevant market' of the product in question. For instance, a pen being sold for 20 euros by a firm is probably sensitive to changes in the prices of pens sold at 22 or 18 euros by competitors. It is probably insensitive to the price of manmade pens (sold at 3000 euros apiece) but it may be sensitive to the price of watches sold at 20 euros if the pens in question and these watches are part of the same relevant market of 'gifts' or souvenirs. This example illustrates how inaccurate the tariff nomeclature approach is since it includes the 3000 euros pens and excludes the 20 euros watches. It also shows that it is hard to say whether the bias introduced by the tariff nomenclature approach overestimates the coverage of the case, or underestimates it. However, what follows provides a likely answer to this question that flows from the high degree of political pressures in anti-dumping (that is, the ability of the complainants to get the best from tariff nomenclature for their own interest).

\section{(ii) Determining injury and causal relation}

There is a huge economic literature testing the economic factors that determine injury (Bloningen and Prusa 2003). Its main lesson is as follows. If economic factors (size of import volumes, profit losses) do matter, political pressures are critical. Such pressures take the form of sectors more influential than others (steel and chemicals in particular) and of countries more often targetted than others. This dominant aspect of political pressures reveals biases built into the anti-dumping procedures.

For instance, an apparently innocuous, but crucial, way of channelling such pressures is the mere number of defendants (firms and countries) involved in an anti-dumping investigation. The practice (known as 'cumulation') of aggregating the exports of several countries (firms) leads to a higher probability of finding injury for the same market share (the condition of a stable market share is essential to make the observation non-trivial). For instance, US cumulated cases examined between 1980 and 1988 are about 30 per cent more likely to result in duties than non-cumulated cases (Hansen and Pusa 1996). The 
reasons for such a bias (known as 'super-additivity') are twofold. A larger number of defendants may reflect higher competitive pressures (lower prices) in the export market than in the case of a smaller number of defendants, hence increasing the probability of finding injury. Alternatively, cumulating defendants is a way to reduce their ability to defend themselves since defence costs have to be shared among a larger number of firms, increasing the risk of freeriding among defendants, hence ultimately their failure (Gupta and Panagariya 2001).

The realization of the importance of political pressures in injury determination has launched a debate on how to improve the methods of assessing injury determination, a debate which echoes the discussions on a similar topic in safeguard enforcement (see the introduction of Chapter 14, on safeguards). What follows presents key aspects of this debate.

Initially, the injury test in anti-dumping has been exclusively based on a 'trend' approach; that is, on descriptive explanations of the evolutions of the key variables in the anti-dumping case, namely the transaction prices for sales of the relevant imports and domestic products and the time series on imports, with a review of the individual transactions in case of alleged lost sales (Morkre and Kruth 1989; Prusa and Sharp 2001). Such trend analyses are necessary and useful, but they have a serious weakness: they are highly sensitive to subjective interpretations.

A first way to improve injury determination relies on modelling the market of a product (CADIC (Boltuck 1991) or COMPAS (Francois and Hall 1993)). Such user-friendly models are based on pre-specified forms of domestic supply, foreign (import) supply and domestic demand. They take the form of spreadsheets requiring analysts to fill up a few cells defining the initial situation (domestic and foreign sales, appropriate (constant) price elasticities and so on) before letting the model run. The main limits of this approach are to be confined to the market of the product in question (it is a partial equilibrium model even if there are more sophisticated versions) and to be heavily dependent on initial data (price elasticities in particular).

An alternative method consists of developing an econometric model of simultaneous relations (equations) of supply and demand. From the demand side, the price of the product under investigation may be stated as a function of several exogeneous variables: for instance, the domestically produced quantity, the price of the imported product from countries under investigation as well as for countries not included in the investigation, the quantities produced of goods derived from the product under investigation (for instance, of autos built from the investigated cold-rolled steel) and so on. From the supply side, the price of the product under investigation may be stated as a function of several exogeneous variables: for instance, the domestically produced quantity (again), the available production capacity the prices of the 
various materials important for producing the product under investigation, and so on. Well oiled econometric techniques allow estimating the coefficients of each of the chosen exogeneous variables, and checking whether the corresponding calculated (predicted) price fits well the observed evolution of the price. If this is the case, the coefficients of each of the exogeneous variables give a sense of their relative impact on the price of the product investigated. In particular, the coefficient of the exogeneous variable 'imports' gives a sense of whether imports have played, or not, a key role in the observed decline of the product price, that is, in the observed injury.

The econometric approach offers a more encompassing analysis than the model approach to the extent that it is based on a wider range of information (it is not just limited to the market if the product is under investigation, but can include a wide range of variables, adapted to each case, from markets of related products). ${ }^{9}$ The negative sides of the econometric approach are that the model may be misspecified (for instance, a critical exogeneous variable is not taken into consideration, or not in an appropriate manner) and that it may require a lot of data. Because all the methods have strengths and weaknesses, the best approach is to see these frameworks as complementary, rather than substitutable, and to use the most appropriate one(s) for each case.

\section{(c) The direct costs of anti-dumping measures}

Firstly, the average level of anti-dumping measures (or their equivalents) is high (within the 25-35 per cent range) with an increasing trend during the last 15 years. As economic analysis shows that the welfare costs of tariffs increase faster than the tariff increases, there is little doubt that the welfare costs of antidumping measures are becoming substantial by this basic standard, as amply documented by many economic estimates (for instance, Murray and Rousslang 1989; Kelly and Morkre 1998; Messerlin 2001) in a partial equilibrium context. However, this conclusion is incomplete.

Secondly, anti-dumping measures are not mere duties. They also consist of quantitative restrictions (quantity undertakings) or minimum prices (price undertakings) decided by the firms in order to avoid paying the anti-dumping duty. In all these cases, anti-dumping measures do not end up in collecting revenues by the government, but in rents captured by private interests. Such anti-dumping measures are frequent because anti-dumping cases often occur in the context of oligopolistic markets. This oligopolistic environment is favoured by the provisions of the 1947 GATT text requiring that the complainants should represent a 'major' proportion of the domestic industry,

9 It also gives a deeper analysis than the decomposition approach described in the introduction to Chapter 14. 
with the 'major' term having often been interpreted as representing more than 50 per cent of the domestic output. Such a provision is a bias favouring complaints by large firms which can achieve this threshold more easily, and at lower costs in terms of coordination of information and lobbying. Moreover, the large size of the data required by complaints and the legal costs of filing complaints introduce additional biases favouring large firms.

The combination of an oligopolistic environment and rent-generating measures (undertakings) means that welfare costs could emerge from changes in the firms' behaviour generated by anti-dumping enforcement. Even if firms behave in a non-coordinated way, they are subjected to incentives to manipulate dumping margin, injury determination and ultimately the new market equilibrium. For instance, efficient and inefficient firms may reduce their exports in order to achieve a lower anti-dumping margin (than in the case where they do not limit their sales). A variant is the case where, in the perspective of a review of the case, foreign firms raise their prices in order to get lower dumping margins, hence indirectly converting tariff revenues into foreign-held rents. A last illustration is the case where the existence of active anti-dumping policies encourage (some) foreign firms to dump in order to trigger anti-dumping cases that will lead to quantity undertakings (VERs) with larger and more stable rents than the initial situation. As a result, the 'dynamic' direct costs of the initial anti-dumping measures can be much larger - ten to 20 times more (Gallaway et al. 1999) - than the initial static direct costs.

All these costs concern the country imposing the anti-dumping measure, but one crucial feature of anti-dumping is to be highly discriminatory at the country and firm level. As a result, a noticeable aspect of anti-dumping costs is the trade diversion generated by such measures (fewer exports from the target countries, more from the other exporters). However, available estimates of trade diversion are mixed: significant in the US (Prusa 1997), not in the EU (Vandenbussche, Konings and Springael 1999). Anti-dumping measures could also generate trade deflection, that is, the fact that exports to the country imposing an anti-dumping measure are deflected to other countries. For instance, there is evidence that, over the period 1992-2001, roughly one-quarter to one-third of the value of Japanese exports to the US thought to be destroyed by US anti-dumping measures was actually deflected to the EU, with substantially lower Japanese export prices in the EU market (Bown and Crowley 2006).

\section{(d) The magnified costs of anti-dumping protection}

So far, non-cooperative behaviour was assumed between foreign and domestic firms, but domestic and/or foreign firms may also behave in a cooperative way, amplifying greatly the direct costs of anti-dumping measures. Contrary to the initial motivation for anti-dumping rules (to prevent foreign cartels from ${ }_{\text {end }} 1848440142$ 
dumping their excess capacity into competitive markets and unfairly harming domestic producers), anti-dumping measures can be used as a pro-cartel mechanism for maintaining pre-existing collusion between foreign and domestic firms (Staiger and Wolack 1989; Messerlin 1989, 1990) or for generating tacit collusion between foreign and domestic firms when collusion does not exist in the first place (Prusa 1992). For a given level of protection, the welfare costs of shifting from initially more competitive markets to less competitive markets can increase tremendously, as illustrated (in an admittedly crude way) by the 40 to 50 per cent increases for a selected number of European cases (Messerlin 2001).

Anti-dumping measures may have such a 'pro-cartel' effect at the two stages of the complaint and of the decision. Firstly, exchanging information for lodging a complaint requires a minimum level of cooperation from the complainants. Even if handled through lawyers, complaining firms could draw 'parallel' conclusions from the complaint. Secondly, nascent collusion between complainants can be made 'sustainable' by anti-dumping measures. It is not by accident that at least one-fourth of EU anti-dumping cases of the 1980s were 'twin' anti-dumping and competition cases dealing with similar products and EU firms (Messerlin 1990). A more systematic indication of this pro-cartel dimension flows from the fact that the combined market shares of the plaintiffs and defendants are often extremely high: on average, around 80 to 85 per cent in the US and the EU. Defendants and complainants have a combined market share of less than 90 per cent in only 55 per cent of the US and EC anti-dumping cases examined in the 1980s and mid-1990s. Foreign cartels (that is, outside the country enforcing anti-dumping measures) have been created by anti-dumping cases, as best illustrated by the quasi-official Canadian potash cartel triggered by US anti-dumping.

Ultimately, anti-dumping may be used by a complaining firm for segmenting the world markets, as best illustrated by cycles, hammers or pocket lighters. It remains to be seen whether such 'echoing' anti-dumping cases are frequent.

\section{B THOU SHALL NOT DISCOURAGE DUMPING (OTHER THAN THROUGH DUTIES)}

Art. 18.1 of the AD Agreement reads: 'No specific action against dumping of exports from another Member can be taken except in accordance with the provisions of GATT 1994, as interpreted by this Agreement.' A footnote to this Article (footnote 24) pertinently adds: 'This is not intended to preclude action under other relevant provisions of GATT 1994, as appropriate.'

It is difficult to speculate what exactly is the ratio legis of this provision. In 
a sense, this provision adds little if anything to the obligations already assumed under the various provisions of the AD Agreement. The footnote at least is clear: assuming during a safeguard investigation some imports are found to take place at dumped prices, the investigating authority can still go ahead and impose safeguards. What else could be covered was for years a matter for speculation.

This provision has been reproduced verbatim from the Kennedy round, to the Tokyo round, to the Uruguay round AD Agreement virtually without any discussion. The view has been voiced that what the founding fathers probably had in mind, besides what the footnote has made clear, was instruments such as the so-called anti-circumvention provisions encountered in some domestic anti-dumping statutes. ${ }^{10}$ In the GATT years, for example, the European Community was condemned for using the anti-circumvention provision in its anti-dumping legislation to impose duties on finished items, parts and components of which were allegedly dumped. Such use was deemed necessary by the European Community since, otherwise, it would be left without any weapons to counteract this form of dumping. ${ }^{11}$

The consistency of Art. 13.10 of the then EC anti-dumping regulation (2423/88) with the GATT rules constituted the subject-matter of the litigation. Art. 13.10 read: 'Definitive anti-dumping duties may be imposed, by way of derogation from the second sentence of paragraph 4(a), on products that are introduced into the commerce of the Community after having been assembled or produced in the Community.' During the Panel proceedings that were requested by Japan, the European Community decided not to advance detailed arguments in defence of its law under Art. VI GATT. It did, however, state that, were the Panellists to take the view that its provision was consistent with Art. VI GATT, it would not disagree. We quote from para. 5.11 of the Panel Report on EEC - Parts and Components:

The Panel further noted, that the United States, as an interested third party, had argued that Article VI of the General Agreement provided to a certain extent a legal

10 See Horn and Mavroidis (2005a). In their view, this is probably one of the reasons why this provision stayed in place since the enactment of such provisions postdates the provision as such.

11 The European Community could not otherwise satisfy the 'likeness' element since a part of a car and a car are not like products. It is interesting to note that the question of alleged circumvention of anti-dumping duties is still on the table. A proposal has been made to recognize in the Agreement two forms of circumvention involving marginal alterations to the product itself, or the above-mentioned minor alterations in the pattern of shipment and assembly. The proposal further suggests that uniform and transparent procedures for conducting anti-circumvention enquiries should be adopted. TN/RL/GEN/29, TN/RL/GEN/106, 
basis for measures to prevent what it considered to be circumvention of anti-dumping duties. At one point in the proceedings the EEC stated that, if the Panel were to find that the anti-circumvention duties were justifiable under Article VI, 'it would not disagree' with such an approach ... However, the EEC presented no arguments in support of a justification of its measures under Article VI. ${ }^{12}$

In the absence of any specific arguments by the defendant, the Panel made no findings on this issue. The relevance of Art. 18.1 AD Agreement for such instruments remained in limbo. During the Uruguay round negotiations, negotiators adopted a decision whereby they decided that the WTO Anti-dumping Committee should deliberate further on the issue of anti-circumvention provisions and their status under WTO law. No action has been taken on this front since then. ${ }^{13}$

The coverage of Art. 18.1 AD Agreement took a new twist with the litigation concerning the consistency of the so-called Byrd Amendment with the multilateral rules. The Panel, in its report on US - Offset Act (Byrd Amendment) had the opportunity to clarify its understanding of Art. 18.1 AD Agreement. In its view, a measure is a specific action against dumping if it satisfies a double condition: it acts specifically in response to dumping and it has an adverse bearing on it. Following this analysis, the Panel went on to find that the Byrd Amendment, whereby only those US economic operators which supported a petition to impose AD duties were promised monetary compensation, in case of course, the petition led to the imposition of duties, is a specific action against dumping (para. 7.18):

A measure is not a 'specific action against dumping' simply because it 'may be taken only when the constituent elements of "dumping" are present', or because it is taken 'in response to' dumping. A measure that may be taken only in situations presenting the constituent elements of dumping is clearly 'specific action' in response to dumping. However, in order for that measure to constitute 'specific action against dumping', something more is needed: the measure must also act 'against' - and therefore have an adverse bearing on - dumping. In other words, a measure will only constitute 'specific action against dumping' if (1) it acts specifically in response to dumping, in the sense that it may be taken only in situations presenting the constituent elements of dumping, and (2) it acts 'against' dumping, in the sense that it has an adverse bearing on dumping. ${ }^{14}$ (Emphasis in the original)

12 GATT Panel Report, EEC - Parts and Components, para. 5.11.

13 As we indicated earlier, a proposal to introduce a circumvention provision in the Agreement has been submitted in the course of the negotiations. TN/RL/GEN/29, TN/RL/GEN/106.

14 Panel Report, US - Offset Act (Byrd Amendment), paras. 7.18 and 7.34. 
On appeal, the Appellate Body (AB) confirmed the Panel's findings. ${ }^{15}$ Recalling its prior pronouncements on this issue $(U S-1916 \mathrm{Act})$, the $\mathrm{AB}$ held that the Byrd Amendment ${ }^{16}$ was inconsistent with Art. 18.1 AD Agreement (paras 255-256 and 265):

The CDSOA effects a transfer of financial resources from the producers/exporters of dumped or subsidized goods to their domestic competitors. This is demonstrated by the following elements of the CDSOA regime. First, the CDSOA offset payments are financed from the anti-dumping or countervailing duties paid by the foreign producers/exporters. Second, the CDSOA offset payments are made to an 'affected domestic producer', defined in Section 754(b) of the Tariff Act as 'a petitioner or interested party in support of the petition with respect to which an antidumping duty order, a finding under the Anti-dumping Act of 1921, or a countervailing duty order has been entered' and that 'remains in operation'. In response to our questioning at the oral hearing, the United States confirmed that the 'affected domestic producers' which are eligible to receive payments under the CDSOA, are necessarily competitors of the foreign producers/exporters subject to an anti-dumping or countervail order.

Thirdly, under the implementing regulations issued by the United States Commissioner of Customs ('Customs') on 21 September 2001, the 'qualifying expenditures' of the affected domestic producers, for which the CDSOA offset payments are made, 'must be related to the production of the same product that is the subject of the related order or finding, with the exception of expenses incurred by associations which must relate to a specific case.' Fourth, Customs has confirmed that there is no statutory or regulatory requirement as to how a CDSOA offset payment to an affected domestic producer is to be spent, thus indicating that the recipients of CDSOA offset payments are entitled to use this money to bolster their competitive position vis-à-vis their competitors, including the foreign competitors subject to anti-dumping or countervailing duties.

All these elements lead us to conclude that the CDSOA has an adverse bearing on the foreign producers/exporters in that the imports into the United States of the dumped or subsidized products (besides being subject to anti-dumping or countervailing duties) result in the financing of United States competitors - producers of like products - through the transfer to the latter of the duties collected on those exports. Thus foreign producers/exporters have an incentive not to engage in the practice of exporting dumped or subsidized products or to terminate such practices. Because the CDSOA has an adverse bearing on, and, more specifically, is designed and structured so that it dissuades, the practice of dumping or the practice of subsidization, and because it creates an incentive to terminate such practices, the CDSOA is undoubtedly an action 'against' dumping or a subsidy, within the meaning of Article 18.1 of the Anti-Dumping Agreement and of Article 32.1 of the SCM Agreement.

15 Bhagwati and Mavroidis (2004) disagree with the AB findings, arguing that there are other, more promising, avenues to attack the Byrd Amendment.

16 Its official acronym is CDSOA (Continued Dumping and Subsidies Offset Act). 
We also stated in that appeal that 'Article VI, and, in particular, Article VI:2, read in conjunction with the Anti-Dumping Agreement, limit the permissible responses to dumping to definitive anti-dumping duties, provisional measures and price undertakings.' As CDSOA offset payments are not definitive anti-dumping duties, provisional measures or price undertakings, we conclude, in the light of our finding in $U S-1916$ Act, that the CDSOA is not 'in accordance with the provisions of the GATT 1994, as interpreted by' the Anti-Dumping Agreement. It follows that the CDSOA is inconsistent with Article 18.1 of that Agreement. ${ }^{17}$ (Emphasis and italics in the original)

This is not an unproblematic decision. Horn and Mavroidis (2005a) point out that it is equally plausible that, as a result of Byrd Amendment payments, exporters continue to dump and possibly, more aggressively so. Consequently, the $\mathrm{AB}$ seems to have punished a statute that might (or might not) disincentivize exporters to continue dumping. This decision, consequently, expands considerably the coverage of Art. 18.1 AD. Where one draws the line is a question of future (jurisprudential) experience. 